\title{
Gender Myths that Instrumentalise Women: A View from the Indian Frontline
}

\section{Srilatha Batliwala and Deepa Dhanraj}

Religious fundamentalism and neo-liberal economic reforms are converting poor grassroots women in India into both agents and instruments in a process of their own disempowerment. Though these forces are not necessarily acting in concert, they are nonetheless reconstructing both gender and other social power relations. While we have analysed this dynamic elsewhere (Dhanraj et al. 2002), in this article we examine the role of certain gender myths - or rather, myth complexes - in this process. ${ }^{1}$ Specifically, we explore the way certain gender myths are being used to convert women particularly poor women - into instruments of both the neo-liberal and fundamentalist agendas in India. The operation of these myths is analysed in the context of a government-initiated rural poverty alleviation programme in southern India and the Constitutionally-mandated reservation of seats for women in local elected councils (panchayats).

At the outset, we wish to emphasise that we do not offer this critical analysis as academic observers, or deny our own participation in these processes. Indeed, the choice of examples is guided at least partly by the history of our own contribution, and the involvement of colleagues whom we supported in various ways. We have both been complicit, through our past roles in grassroots activism, feminist training and advocacy, in promoting various gender myths and feminist fables that we have only recently begun to recognise as such. Thus, it is not our intention to point fingers or place blame. The analysis that emerges here is the result of critical introspection, of re-examining our own as well as others' past assumptions and interventions. We believe this is a critical moment when all feminists - whether activists, policy advocates or researchers
- must interrogate our own assumptions and strategies, or risk becoming completely marginalised and/or instrumentalised by the forces of resurgent patriarchy, religious fundamentalism and neoliberalism.

\section{Gender myth complex I} Giving poor women access to economic resources - such as credit - leads to their overall empowerment

This myth arose out of successful feminist efforts to shift economic resources into women's hands, gain recognition for women's roles in household economies and support women's leadership in local development. Feminist efforts were of course rooted in an understanding that economic power and access to productive resources would weaken traditional gender and social roles and empower poor women to demand further change. But as these strategies began to demonstrate the soundness of investing in women's entrepreneurship and leadership, they were quickly converted into a new development mantra: poor women are now considered the best economic and political investment. At the international level, the World Bank, USAID, DFID and other bilateral and private donors have embraced and enthusiastically promoted the new formula. At the national level, both central and state governments and rural banks have begun to actively promote self-help groups and women's savings and credit programmes through schemes such as Directorates of Women and Child Development (DWCRA), the Indira Mahila Yojana and now, Swayamsidha. The creation of special Directors for Micro Credit and in many state DWCRA tells its own story. 
The conceptual legerdemain achieved here is neatly summed up by Mary John. She observes that a nationwide study like Shramshakti (National Commission on Self-Employed Women and Women in the Informal Sector 1988) recorded an enormous pile of evidence of the incredible burdens borne by poor self-employed and informal-sector working women in India; but in the hands of neoliberal advocates, 'these findings are no longer arguments about exploitation so much as proofs of efficiency' (John 2004: 247, own emphasis). Poor women are now seen as harder working, easier to mobilise, better credit risks, more selfless because they are concerned with their entire families and communities, more loyal voters, the best anticorruption vigilantes, and the best agents to uplift their families and communities. Obviously, many of these statements are generally true. The mythical dimension arises when qualities born out of women's struggle for survival are exploited for political and economic ends, rather than from a commitment to their empowerment.

In India, one of the most high-profile propagators of this myth is the former Chief Minister of Andhra Pradesh state, Mr Chandrababu Naidu. His affinity for high-tech corporate management systems has earned him the epithet "The CEO of Andhra Pradesh" and the foremost proponent of "Egovernance". From 1999, when Andhra Pradesh launched an economic restructuring project under his leadership, he decided to use rural women as key instruments of his policies - and of his political strategy for staying in power. In the Indian context, such restructuring had to include a major antipoverty component to appease the mass of poorer rural voters, who were unlikely to benefit from the deregulation, improved investment incentives and removal of bureaucratic hurdles, that facilitated the urban affluent classes. In Mr Naidu's case, the modus operandi was to create government-owned NGOs (amusingly called "GONGOs" in some quarters), administered by elite Indian civil service officers. Mr Naidu made it clear to both his party cadres and government functionaries that implementation would be through grassroots women's groups. In the Indian realpolitik, this signalled that the only political constituency he was interested in building was women, and he conflated women with "poor", "rural" and "community".

Thus it was that the largest poverty alleviation programme in the state focused entirely on rural women: the World Bank-funded District Poverty Initiatives Project, with a budget of 26,000 million Indian Rupees (US\$553 million, UK£333 million) in 20 districts of the state. Headed by carefully selected officers of the elite Indian Administrative Service, the project begins with the identification of all formations of women at the village level (selfhelp groups, Mahila Mandals, Bhajan Mandalis). ${ }^{2}$ Simultaneously, NGOs were identified to conduct training for the women's groups in gender issues, income generation activities, and financial skills such as accounting and book-keeping.

Although the project was initially designed to enable the women's groups to determine and create local projects based on their priorities (including building community assets like drinking water pumps), it was soon reduced to distributing loans to individual women for income-generating activities. Very poor women soon fell out of the net because they could not pay the weekly contribution required to retain membership of the self-help group. In a short while, only women with some stable earning capacity remained in the groups.

The project also tried to improve women's access to and relations with markets. For instance, women who gathered and sold tamarind were always swindled by middlemen who drove down purchase rates and used falsified weights and scales. An internet-based system was therefore introduced to check market rates on a daily basis, in order to give women more bargaining power. But many women could not exercise that power since they were heavily indebted to the buyers. The self-help group was simply not a powerful enough structure from which to challenge weights and measures or purchase prices, as a cooperative or trade union might have been - particularly since rights awareness and strengthening the capacity for collective struggle were not part of the organising strategy for such groups.

The project's community organisers also began to press women to take multiple production loans; and the number of hours they were working increased dramatically - there was no other way to keep pace with their mounting debt. But if one converted their profits from all these enterprises into wages, not one of them was earning even the minimum daily wage. At a workshop on 'Rethinking Micro-Credit', held at the recent World Social Forum in Bombay, rural women from different parts of the country spoke passionately about their multiple 
debt burdens and how repayment had increased their workloads to inhumane levels. Yet, the project continually cites these women as models of entrepreneurship - not surprising since the only indicator they use is monthly cash turnover. Meanwhile, men in project villages have become sullen and resentful. Women handling so much money has become a source of humiliation; they neither understand nor acknowledge the women's onerous workload, or the debt-trap which gives no respite. Thus, apart from being overworked and anxious about mounting interest and repayments, women have to deal with this growing hostility and possibly violence - from men in the home.

But far worse is the assumption behind the project's strategy: once money is handed over in the form of loans, the women are responsible for improving their lot, and the state's role is over. At the same time, this munificence will earn the ruling party rural women's allegiance, and secure its political future. The women's political agency has been reduced to the privilege of being agents, consumers and beneficiaries of state-controlled credit and micro-enterprise programmes, with no other investment in improving the condition of their daily lives. There are no investments, for example, in providing cooking fuel, water close to the home, or day care for younger children, so that older daughters can go to school. Women are so preoccupied with earning income to repay loans that they have little time or energy to participate in other public affairs, or organise other issues.

Ironically, this is the very same region of India that once saw massive participation by poor women in large-scale political movements (such as the armed struggle in Telengana, see Sanghatana 1989; Sen 2000: 24) for land, for minimum wages, in protests against rise in price of basic commodities, against the sale of country liquor that beggared families while filling state coffers with revenue. Now, the women of this same region are being converted into passive instruments of the regime's single-point anti-poverty measure, with little or no capacity to negotiate for a different agenda or approach. The humiliating rout of Mr Naidu's party in the May 2004 state elections in Andhra Pradesh could at least, in part, manifest women's rejection of his political strategy and policies, and their attempt to reclaim political agency through the ballot box.

This kind of narrowed focus is not unusual in credit-focused strategies. A decade ago, staff of BRAC, a Bangladeshi NGO famous for its very large-scale women-focused poverty-alleviation programme, acknowledged the same in a review of the gender impact of their work:

The evidence suggested that participation in BRAC's programs had strengthened women's economic roles and, to some extent, increased women's empowerment measured in terms of mobility, economic security, legal awareness, decision making and freedom from violence within the family. However, widely acknowledged among BRAC staff was the fact that the imperatives of credit delivery were eclipsing the objectives of social change. (Rao, Stuart and Kelleher 1999: 43)

Programmes to alleviate poverty are obviously rooted in ideological frameworks. This programme demonstrates the heavy influence of the neo-liberal paradigm: it has been designed to ensure that people - for which read women - participate in the narrowest possible form of economic development in the most apolitical and disempowering way imaginable. As Lucy Taylor argues, the neo-liberal agenda requires the state to keep those "who have not forgotten their politicised past ... busy and out of harm's way, distracted from wider political considerations and submerged within the minutiae of issues in their own backyard' (1996: 785).

The neo-liberal agenda, Taylor suggests, requires citizens to accept the reformed identity of the state as facilitator, not provider, of social and individual betterment. It also demands the twin identities of citizen and individual - i.e. the active, socially responsible citizen and the active, socially responsible individual who is in charge of her own destiny. The neo-liberal rules for the new woman citizen, as evidenced in the Andhra Pradesh project, are quite clear: improve your household's economic condition, participate in local community development (if you have the time), help build and run local (apolitical) institutions like the self-help group; by then, you should have no political or physical energy left to challenge this paradigm. These rules sustain a sort of depoliticised activism at the local level - one that inherently does not build upward momentum.

Why should this concern us? Is it not enough that poor women have gained greater access to 
productive resources? It is the experience of Gujarat state, with some of the oldest and largest networks of women's credit and income-generation groups, that challenges such complaisance. It is in this state that totalitarian, fundamentalist, anti-poor ideologies and their cadres, largely undisturbed and unchallenged, have waged their violent politics at the grassroots level. And this is also the state where the most horrifying and organised carnage against the Muslim minority (the worst since the partition of India in 1947, with Muslim women being particularly targeted) was unleashed by Hindu mobs in early 2002.

Despite extensive grassroots-level women's economic empowerment programmes, mostly operated by NGOs, and which have ostensibly promoted a tolerant, unifying value system, neither Muslim nor Hindu members of these networks seem to have been aware of the approaching carnage, or of the vicious hate campaign that we now know was being spread for at least a year before the pogroms (Khan 2002). In the very neighbourhoods in which these women lived, the aggressively fundamentalist Vishwa Hindu Parishad had been actively mobilising women into Durga Vahinis (women's militias), and providing arms training (to defend themselves against the insatiable sexual appetite of minority men). It seems incredible that none of this came to the attention of women in the micro-enterprise or self-employed groups that dot the state ... unless it was because they were so narrowly focused on their economic activities that they never sensed the political winds blowing through their very villages and neighbourhoods. Or was it because the discussion of larger politics was never included on weekly or monthly women's group meeting agendas?

What we are seeing is a confusing picture where on the one hand, fundamentalist agendas are actively mobilising women of all classes in their movements, and on the other, the political agency of large numbers of poor women is being dissipated through a model of citizenship and participation that is being promoted in a very instrumentalist fashion by the state and its international allies. It is frightening indeed to contemplate the fact that in India, the only force currently interested in empowering poor women as political actors is the Hindu fundamentalist movement.

\section{Gender myth complex II}

If women gain access to political power, they will opt for politics and policies that promote social and gender equality, peace and sustainable development. Thus, quotas or other methods of ensuring high proportions of women in elected bodies will transform these institutions. Women will alter the character of political culture and the practice of public power. (United Nations 1995)

It is not hard to understand how this fable came into being (sometime in the 1970s, we think). Male domination of public power and politics had led to the destruction of life, humanity and the earth itself. Even in so-called "liberal democracies", the notion of democracy itself had been reduced, as the late Claude Ake pointed out, to a minimalist version, where the main privilege enjoyed by citizens is that of some protection from state power (Ake 1996). As feminists from the North and South began to expand and deepen their understanding of the roots of gender discrimination, they argued that women's access to power and decision-making authority in the public realm was as critical to achieving gender equality as changing power relations in the private sphere of households (UN Beijing Declaration and Platform for Action, Strategic Objectives G.1 and G.2). Looking back, and again, having been part of this process, we believe there were several implicit and explicit assumptions underlying this analysis, including:

- that the transformation of both the position and condition of women (Young 1988) - i.e. meeting both their practical and strategic needs - could only be achieved and sustained in macro terms through political change (enabling policies, legislation and the protection and enforcement of women's rights)

- that women representatives in local, national and global political bodies would advance the cause of gender equality and women's rights and sustain the momentum for such change over time

- that a critical mass of women in political institutions would also initiate policies of development and international relations that would advance social and economic justice and peace, by fostering and promoting non-violent conflict resolution, sustainable and socially just 
development, access to and protection of the full body of human rights, and placing people and the environment above profits

- that a critical mass of women in political institutions would transform the very nature of power and the practice of politics through values of cooperation and collaboration, holding power in trusteeship (power on behalf of, not over) and acting with greater transparency, honesty and public accountability. In other words, there was a belief that women would play politics differently and exercise power accountably.

With the wisdom of hindsight, we can see how these assumptions reflected our then limited understanding of citizenship, and of how citizenship was constructed in not just gendered ways, but through other categories of social power. We assumed that citizenship was a fixed and bounded terrain, rather than that 'like power relations, citizenship rights are not fixed, but are objects of struggle to be defended, reinterpreted and extended' (Meer with Sever 2004: 2). We believed that once women had access to political power, they would act for greater justice and equity. The push for getting women into politics became strong and visible in many parts of the developed and developing world by the mid1970s, and by the 1990s, several European countries, the USA, and developing countries such as India, the Philippines, South Africa, Uganda, Brazil, Chile, Mexico and many others had large numbers of women in their political parties and governing institutions at various levels. In some contexts - notably India and South Africa - "pull" factors like quota systems were used; in others, such as the USA and some parts of Western Europe, "push" factors (mainly pressure from women's movements) worked effectively to increase the number of women elected representatives. Over time, feminist struggles to promote women's greater representation and participation in politics were picked up and encapsulated into modules and templates by international donor agencies and other institutions that began to promote the new "good governance" agenda, particularly in the South.

It would be a grave disservice to thousands of courageous women to say that all the assumptions about their impact on public policy, politics and power have been belied. But the experience of the last two decades forces us to confront some troubling realities and recast our vision for transformation through political power.
The most worrying phenomenon at the present time is that the expanding space for women in politics has been seized far more effectively by right-wing, conservative and fundamentalist parties and agendas. In the USA, for instance, while the Democrats boasted of having fielded the largest number of women candidates for both Congress and Senate, Republicans are rapidly closing the gap. As the Gender Gap website says, 'several trends indicate there will be larger gains in the future. More women are running for office. Far more women are winning their primary races ( 73 per cent of female House candidates won their primary, up from 57 per cent in 1996 and 48 per cent in 1992). Both major parties are more actively courting female candidates who have proven they can wage a strong campaign. Christian fundamentalist groups, with their close affiliation to conservative political agendas, are the ones that have mobilised poor and middle class grassroots American women voters and activists on a very large scale, not the progressive movements or parties. ${ }^{3}$

In South Asia, the huge mobilisation of women by religious fundamentalists, including the fielding of women political candidates, is nothing short of frightening. ${ }^{4}$ Before the current general elections, there were four women Chief Ministers of various Indian state governments, the highest in postIndependence history - and all of them were members of the ruling Hindu nationalist party, or its close allies. This first became evident when the media flashed images of thousands of Hindu women across the country joining the marches and the symbolic carrying of construction material to the Babri Masjid, the ancient mosque destroyed by Hindu fundamentalist mobs in 1992, to rebuild the Ram temple that was allegedly destroyed when the mosque was built. The images became more aggressive during the anti-Muslim riots in Bombay in 1993: hundreds of Hindu women made petrol bombs that their men then hurled on Muslim shanties. The pinnacle, however, was reached before, during and after the anti-Muslim pogroms in Gujarat state in early 2002, when thousands of Hindu women, both poor and middle class, actively supported the attackers, joined in the looting of Muslim shops and marched in massive numbers in the political rallies and processions that were held in support of the state's fundamentalist regime.

To dismiss this phenomenon simply as a result of false consciousness, or the instrumentalisation of passive women by cynical and sinister leaders, 
is a grave mistake. Seen from close up, women's participation in these movements is far from passive or blind, but very much through their active agency. As we have argued elsewhere (Dhanraj et al. 2002), the fact is that fundamentalist movements have created a genuine political space and role for women. They have given them the possibility of being real political actors, an active sense of being architects of a grand public project, of building a new society. Regrettably, this is something which neither other political parties, nor the labour movement, nor progressive social movements (including feminist women's movements) have done on the same scale or with the same deadly sense of purpose. It is also unfortunate that in the current Indian scenario, the Hindu fundamentalists are the most effective and deliberate in deploying mass mobilisation strategies, and have the most conscious programme of women's mobilisation within them.

Meanwhile, India boasts of nearly one million elected women in its village and town councils, thanks to the passing of the 73rd Amendment to the Constitution of India, in which Indian feminists had little role. This Amendment made it mandatory for 33 per cent of all positions in local councils to be reserved for women. There were also reservations for Dalit and tribal men. This was brought about by well-intentioned Gandhian advocates and bureaucrats who envisaged a form of local governance and decentralisation that would transform rural India, a social revolution that could redress centuries of marginalisation for both Dalits and women, orchestrated by the State.

The discourse on the impact of this unprecedented structural change, the largest scale experiment of its kind anywhere in the world, is rather banal for the most part. It is also quite polarised, between gloomy stories of women's cooption or subversion on the one side, and cheering protagonists on the other, who dismiss criticism or any analysis that is less than laudatory. Both positions are often derived from anecdotal evidence and ideological positions, rather than a serious inquiry into what is actually happening. There are, of course, some large-scale and highly quantitative studies, but these fail to capture many of the complexities and nuances of the reality. They tell us little about what it has meant for elected women and men from poor castes and communities, how they are negotiating their roles in the councils and the nature of grassroots political culture and functioning.
What we have witnessed on the ground - as documented in Dhanraj's film Taking Office - is a complex picture, where both patriarchal and feudal/semi-feudal gender and social power relations are simultaneously being challenged, changed, accommodated, and modified at the same time. A landless Dalit woman labourer is elected to and becomes the Chairperson of a village council in which her upper-caste landlord (or his wife) is also an elected member. Dalit, tribal, other oppressed caste and minority women and men elected representatives have to negotiate a vast and dangerous minefield of class and caste politics, patronage networks, and affiliations, while the social and economic bases of their lives outside the panchayat remain unchanged. We know of elected women who have been placed under virtual house arrest for attempting to challenge budget allocations; they have been beaten up, threatened, bribed and cajoled into supporting dominant caste or class agendas in the Councils. We find that since most women have entered these institutions without any kind of political or ideological training, skills or experience - they have not been members of a political party or cadre, for example - or have only the limited apolitical experience of their participation in a village self-help group, they are forced to learn and acquire these skills in the most arduous ways and at great cost. We have seen women devote all their time and energy to simply learn how to steer through the maze. Many have amazingly triumphed over these odds and managed to deliver a few resources to their constituency. Indeed, most of the elected women with whom we have interacted are far from passive puppets. They show remarkable resilience in repeatedly trying to exercise their agency, to fulfil their responsibilities, to flex their political muscles, or simply to function autonomously.

A major handicap, we find, is that these women struggle in the absence of any alternative models of power. As Anne Marie Goetz (2003: 3, 5-6) points out, their images of leadership and experience of the exercise of power are gained within the family/household, from the feudal and caste-based social and economic structures they live in, and the few state and non-state institutions they have interacted with in their lives: the school, the local government officers, and maybe rural NGOs and development organisations. None of these are exactly models of alternative politics, much less innovative practitioners of power. Feminist activists have 
attempted to create these alternatives in a few locations - but more often, women's groups are quick to stigmatise these elected leaders for becoming coopted or corrupted by the dominant political culture, rather than supporting them to create an alternative. Apart from celebrated examples - Indira Gandhi, Benazir Bhutto, Margaret Thatcher, Jayalalitha, etc. - there are growing numbers of "Women with Moustaches", as Latin American feminists have called them, in politics at all levels today: hard-nosed, tough, aggressive and sometimes corrupt women politicians. We believe it is much too simplistic to dismiss this as the result of male consciousness masquerading in female bodies. Nevertheless, in a country like India, there are very few successful elected women to serve as mentors or models.

\section{Conclusion}

The above analysis of the operation of two major gender myths seems to suggest that a larger project is at work in India - one that is constructing and then utilising women as particular types of social, economic and political citizens.

The myth of women as the best anti-poverty agents and investments, and the mass-scale creation of women's self-help groups, seems to be nurturing a form of depoliticised collective action that is completely non-threatening to the power structure and political order. These groups, forced to focus all their energies on their productive activities, their loan repayments and the survival of their collective, seem to be rendered oblivious to the ideological/political mobilisations going on under their very noses. Lucy Taylor's analysis of the reinterpretation of civil society and citizenship in Chile in the dictatorship and post-dictatorship years, where the 'twin strategies of incorporation and marginalisation' (1996: 780) were used, demonstrates not only how self-help groups were the policy instruments of this agenda, but that this strategy is not unique to India.

We are not suggesting that economic empowerment programmes for women are either disempowering or unmitigated failures. The successes of micro-credit for women are well documented (see ILO 1998) and there is little purpose in raising yet another paean to them here. Our purpose, rather, is to highlight the manner in which such interventions are being designed and delivered in increasingly disempowering ways, instrumentalising poor women, and being distorted to serve other agendas.
On the political front, far from women transforming politics, evidence of the reverse is mounting. Particularly disturbing is the way in which fundamentalist parties have fostered women's political participation to advance their agenda. At the grassroots level, we are witnessing both this kind of instrumentalisation and the marginalisation of women elected representatives in multiple ways, in a manner very similar to what is happening in other parts of the world (Goetz and Hassim 2003). As one analysis puts it, 'the system of representation that gives women "authority" through holding an elective post has not transformed into actual "power" (Vijaylakshmi and Chandrasekhar 2001).

What is clear, however, is that the myths regarding women's capacity to transform both politics and public power have been central to all these processes. We clearly underestimated the power of existing modes of power and politics to corrupt, co-opt, or marginalise women, or how it would compel or manipulate them to compromise their goals for narrow party interests. And we failed to address the possibility that women would be proponents of reactionary, sexist, racist, elitist or fundamentalist ideologies.

Thus, if we combine the mobilisations of women by the fundamentalist agenda, the depoliticised forms of collective action promoted by statesponsored micro-credit programmes, and the subversion of the agency of elected women in panchayats, what emerges is a deeply problematic and bounded construct of women's citizenship - a construct that must be seriously analysed, challenged, and re-framed. But this is also a serious learning moment for feminists. We are clearly at a historic juncture where the marginalisation of feminist critiques and corporatisation of feminist strategies forces us to recast our analyses and approaches. This cannot be achieved without looking closely at what is happening to women on the ground. Using the lens of gender myths helps us unearth the deeper, more fundamental processes of restructuring power and politics that are afoot - the ways in which resurgent patriarchy, neo-liberal economics and fundamentalism are combining to construct a new kind of female citizen. The challenge now is to move towards more nuanced and contextualised approaches that can hopefully begin to confront and contain these formidable forces. 


\section{Notes}

1. For the purpose of this article, we are treating gender myth as the 'feminist insights [that] become mythologised as they become development orthodoxy', and feminist fables as assumptions and analyses that informed strategies advanced by feminists themselves. Some of the most problematic of today's gender myths are not single ideas but a web of interlinking beliefs and views.

2. These are women's clubs and the equivalent of Western choral societies.

\section{References}

Ake, C., 1996, 'Mistaken identities: how misconceptions of relations between democracy, civil society and governance devalue democracy', Keynote Paper for the International Workshop on Government, Getulio Vargas Institute, São Paolo, Brazil, November

Dhanraj, D., Batliwala, S. and Misra, G., 2002, 'Facing the future: a South Asian perspective on challenges for the women's movement', AWID Ninth Forum, 'Re-inventing Globalization', Guadalajara, Mexico, 3-6 October, Occasional Paper 2, www.awid.org/forum/, and forthcoming in J. Kerr and E. Sprenger (eds), Feminist Futures, Amsterdam: Mama Cash

Goetz, A.M., 2003, 'Political cleaners: how women are the new anti-corruption force', paper presented at the conference 'Gender Myths and Feminist Fables: Repositioning Gender in Development Policy and Practice', 2-4 July, Institute of Development Studies, Brighton

Goetz, A.M. and Hassim, S., 2003, No Shortcuts to Power: African Women in Politics and Policy Making, London: Zed Books

ILO, 1998, 'Women in the informal sector and their access to microfinance', paper prepared by the International Labour Office (ILO) for the InterParliamentary Union (IPU) Annual Conference, Windhoek, Namibia, 2-11 April

John, M., 2004, 'Gender and Development in India, 1970-90s', in M. Chaudhuri (ed.), Feminism in India, New Delhi: Kali for Women and Women Unlimited

Khan, Z.-I., 2002, 'New evidence that Gujarat pogroms were preplanned', www.milligate.com/ Archives/01112002/0111200291.htm
3. It was interesting to note, for example, that African American women were the single largest constituency opposed to the war on Iraq, yet have never been significantly mobilised by any progressive movement in the USA after the civil rights era.

4. The Vishwa Hindu Parishad has launched special training camps for young Hindu women to act as 'Protectors of the Faith', including training in the use of swords and other weapons.

Meer, S., with Sever, C., 2004, 'Gender and citizenship: overview report', Bridge Pack on Gender and Citizenship, Brighton: Institute of Development Studies

National Commission on Self-Employed Women and Women in the Informal Sector, 1988, Shramshakti, Delhi: Government of India, Ministry of Human Resource Development

Rao, A., Stuart, R. and Kelleher, D., 1999, 'Building gender capital at BRAC: a case study', in A. Rao, R. Stuart and D. Kelleher (eds), Gender at Work - Organizational Change for Equality, Connecticut: Kumarian Press

Sanghatana, S., 1989, We Were Making History - Life Stories of Women in the Telengana Struggle, New Delhi: Kali for Women

Sen, S., 2000, 'Toward a feminist politics? The Indian women's movement in historical perspective', World Bank Policy Research Report on Gender and Development, Working Paper Series 9, Washington, D.C.: World Bank

Taylor, L., 1996, 'Civilising civil society: distracting popular participation from politics itself', Contemporary Political Studies, proceedings of the annual conference held at the University of Glasgow, Political Studies Association, www.psa.ac.uk/cps/1996.htm: 778-85

United Nations, 1995, Beijing Declaration and Platform for Action, New York: United Nations

Vijaylakshmi, V. and Chandrasekhar, B.K., 2001, Authority, Powerlessness and Dependence: Women and Local Governance in Karnataka, Bangalore: Institute of Social and Economic Change

Young, K., 1988, Gender and Development: A Relational View, Oxford: Oxford University Press 